\title{
Subcellular Localization of Glycolipids as Revealed by Immuno-Electronmicroscopy
}

\author{
免疫電子顕微鏡により明かにされた糖脂質の細胞内分布
}

\begin{abstract}
Wim F. Voorhout ${ }^{1 *}$, Ida L. van Genderen', Tohru Yoshioka ${ }^{2}$, Kiyoko Fukami ${ }^{3}$, Hans J. Geuze ${ }^{1}$, and Gerrit van Meer ${ }^{1}$.
${ }^{1}$ Department of Cell Biology, Medical School AZU H02.314, University of Utrecht, 3584 CX Utrecht, The Netherlands,

FAX: 31-30541797, ' Department of Human Basic Sciences, School of Human Sciences, Waseda University,

Tokorozawa, Japan, and ${ }^{3}$ Department of Biosignal Research, Tokyo Metropolitan Institute of Gerontology, Tokyo, Japan.
\end{abstract}

Key Words: Forssman glycolipid, immunogold-labeling, freeze-substitution, PIP $_{2}$, electron microscopy

\section{Abstract}

New insights in the distribution of lipids over the various intracellular organelles have been gained by a newly developed method for the immuno-localization of lipids. The method involves the labeling of an antigenic lipid with an antibody followed by a protein A-gold probe. Labeling is performed on ultrathin sections after freeze-substitution and low temperature embedding of aldehyde-fixed and cryo-protected cells. In a first study, Forssman glycolipid was localized in epithelial MDCK cells. Abundant labeling of the plasma membrane, the Golgi complex, and the membranes of the endocytic pathway was in contrast with the complete absence of labeling from mitochondrial and peroxisomal membranes. This demonstrated the specificity of the method. Recently, the method has also been applied to the(glycophospho)lipid phosphatidylinositol 4,5-bisphosphate( $\left.\mathrm{PIP}_{2}\right)$, the central component of the phosphoinositide signal transduction pathway. In MDCK cells, two monoclonal antibodies labeled the plasma membrane, whereas membranes of the Golgi complex were virtually negative. One monoclonal in addition yielded abundant labeling over the heterochromatin in the nuclear matrix, whereas the other monoclonal antibody yielded only minor labeling dispersed over the nuclear matrix. This labeling in the nuclear matrix suggests the occurrence of a non membrane-associated form of PIP $_{2}$, most likely complexed to a nuclear protein. The general applicability of the method is discussed.
要 約

細胞内小器官における脂質の分布に関する新しい知見が脂 質の局在を免疫学的手法で検出する、新たな方法の開発により 集積しつつある。この方法は、特異的抗体によって脂質抗原を 標識し、さらにこれを金粒子結合プロテインAをプローブとし て検出するものである。すなわち、アルデヒド固定して凍害防 止した細胞を凍結置換、低温重合樹脂を用いて包埋後、超薄切 片を作成して標識を行う。この方法を用いて行った最初の研究 で、フォルスマン糖脂質の上皮性の腎ガン細胞株(MDCK細胞) における分布を観察した。フォルスマン糖脂質は、細胞膜、ゴ ルジ体およびエンドソームに多く分布しているのに対して、ミ トコンドリアやペルオキシゾーム膜には全く観察されなかっ た。この観察結果は、本法の高い特異性を示した。近年この方 法は、ホスホイノシトール代謝系の情報伝達経路において中心 的な役割を担っている、フォスファチジルイノシトール4,5-二 $\left(\mathrm{PIP}_{2}\right)$ リン酸の細胞内分布の観察にもまた応用されている。 MDCK細胞をPIP 2 に特異的な二つのモノクローナル抗体を用い てその分布を解析したところ、細胞膜は両者の抗体で標識され た。ところが、ゴルジ体の膜は全く標識されなかった。さら に、その内一つのモノクローナル抗体は、核内基質である異質 染色質をも強く標識した。しかし、他方の抗体での標識は弱 く、核内基質に散在していた。 PIP 特異的抗体によって核内基 質が染色されたということは、 $\mathrm{PIP}_{2}$ が非膜結合性、すなわち核 内タンパク質と複合体を形成したのではないかと思われた。こ の方法の一般的応用について議論する。

\section{A. Introduction}

In most animal cells, glycolipids are a quantitatively minor class of membrane lipids. However, for a variety of reasons interest in these lipids has been soaring over the last years, not the least of which is the realization that a remarkable number of onco-developmental antigens have turned out to be glycolipids(1). $\mathrm{T}$ he animal glycolipids fall into three categories according to their lipid backbone. The first category are those

"Present address: Department of Functional Morphology, Faculty of Veterinary Medicine, University of Utrecht, Utrecht, The Netherlands.

\section{A. はじめに}

ほとんど全ての動物細胞において、糖脂質は膜脂質におい て微量成分である。ところが、近年、種々の理由から糖脂質が 注目されている。特に、ガンや発生に伴って変化する抗原の多 くが糖脂質であることが示されている(1)。動物の糖脂質は、そ の脂質構造から 3 つに分類される。まず第一に、脂質部分がドリ コール構造のものである。この構造を有する糖脂質は、ER内人 の糖の運搬を介在する中間体であり、タンパク質のN型糖鎖合 成過程に関与している(2)。第二には、Nーアシルースフィンゴシ ン(セラミド)構造をも持つ、いわゆるスフィンゴ糖脂質であ る。スフィンゴ糖脂質における種々の特異的な糖鎖配列は、細 
with a (phospho)dolichol backbone. They serve as intermediates in the translocation of carbohydrates into the ER lumen and onto a protein in the process of $\mathrm{N}$-glycosylation(2). Glycolipids of the second type possess a $\mathrm{N}$-acyl-sphingosine backbone (ceramide), the glycosphingolipids. While the specific carbohydrate sequences of various glycosphingolipids have now been shown to be involved in recognition events at the cell surface(3-5), their breakdown products have been implied in signal transduction $(3,6)$. In addition, it has been suggested that glycosphingolipids along the intracellular transport routes are involved in sorting membrane components to specific locations in the cell(7). The third type of glycolipids contains a diacylglycerol backbone. While the latter class includes the monoglycosyl- and diglycosyl-diacylglycerols, in animal cells the most abundant members are the glycophospholipids phosphatidylinositol(PI) and its phosphorylated derivatives phosphatidylinositol 4-monophosphate(PIP) and phosphatidylinositol 4,5-bisphosphate( $\left.\mathrm{PIP}_{2}\right)$, which are central components in the signal transduction cascade known as the phosphoinositide pathway $(8,9)$. PI can also be further glycosylated to serve as a glycosylphosphatidylinositol(GPI) anchor for membrane proteins(10).

\section{B. Intracellular Organization of Glycolipids by Biochemi- cal Methods}

\section{B-1. Glycosphingolipids}

From the fact that glycosphingolipids have been found exposed on cell surfaces and from the idea that that is where they fulfill their main functions, until recent years the prevailing opinion has been that the bulk of the glycosphingolipids is expressed at the cell surface(11), an extreme example of which is found in the apical plasma membrane domain of epithelial cells from the intestine. Their apical surface turns out to be virtually covered by glycosphingolipids(12). However, cell fractionation work has suggested that in fact no major differences in lipid composition exist between the plasma membrane and the membranes of the endocytotic route: the endosomes and the lysosomes(13). In addition, glycosphingolipids have been found in the organelle where they are assembled, the Golgi complex. Whether or not (low levels of) glycosphingolipids are present in other cellular membranes like the ER and its specialized domain the nuclear membrane could not be convincingly solved by cell fractionation due to inherent problems of cross-contamination. One other general belief has been that glycosphingolipids are exclusively expressed on the non-cytoplasmic face of cellular membranes(11). This notion has recently been challenged by the observation that the simple glycosphingolipid glucosylceramide is synthesized on the cytoplasmic surface of the Golgi complex(14-16), while also the next step in the synthesis of most complex glycosphingolipids, the transfer of galactose to yield lactosylceramide, may or may
胞表面上での細胞間認識機構に関与していることが示された(35)。また、スフィンゴ糖脂質の分解産物は細胞内情報伝達に関 わっているらしい(3、6)。さらに、細胞内輸送経路にそって分 布するスフィンゴ糖脂質は、膜成分を細胞内の特定部位への運 搬に関与しているらしい(7)。第三の型は、ジアシルグリセロー ル構造をもつ。それは、ジアシルグリセロールに単糖または二 糖が付加した形で存在している。動物細胞において、この分類 に含まれる糖脂質の中で最も多量に存在するのが、糖リン脂質 であるフォスファチジルイノシトール(PI)と、その誘導体であ るフォスファチジルイノシトール4-ーリン酸(PIP)およびフォス ファチジルイノシトール4,5-二リン酸( PIP $\left._{2}\right)$ である。これらは、 フォスフォイノシタイド代謝経路として知られている情報伝達 カスケードの中心的な成分である(8、9)。また、PIにさらに糖 鎖が付加されることによって膜タンパク質のGPIアンカーとし て携わることができる(10)。

\section{B. 生化学的方法による細胞内小器官の糖脂質}

\section{B-1. スフィンゴ糖脂質}

スフィンゴ糖脂質は、細胞表面に露出しているという事実 と、糖脂質の主たる機能はその膜上で行われているという考え から、今日まで極めて一般的な考えとして、スフィンゴ糖脂質 に含まれる大部分が、細胞膜に発現していると思われている (11)。その最も良い例として、腸の上皮細胞の頂端側の形質膜 にスフィンゴ糖脂質が見い出されることが上げられよう。この 上皮細胞の頂端側表面は、事実、極めて多量のスフィンゴ糖脂 質によって覆われていることが判明している(12)。しかし、細 胞分画の研究から、形質膜とエンドサイトーシス由来の膜、す なわちエンドソームとリソゾームの両者の間における脂質成分 には、主たる違いは認められない(13)。さらに、スフィンゴ糖 脂質は、それが合成される場であるゴルジ体においても見いだ されている。しかし、スフィンゴ糖脂質が多少なりともERや ERが特殊化した部位である核膜のある特定部位にも存在してい るのではないかということについては、細胞分画法では分画成 分の相互の混入があるために明快な解析ができない。一般的に 信じられていることとして、スフィンゴ糖脂質は、細胞膜の細 胞質内側には存在しないということである(11)。しかし、近 年、その概念は、単純スフィンゴ糖脂質であるグルコシルセラ ミドがゴルジ体の細胞質側表面において合成されているという 事実から覆ろうとしている(14-16)。また、グルコシルセラミド からガラクトース転移によるラクトシルセラミドの合成は、サ イトゾールであるのか否かという問題がある(7、17)。この点に 関して、スフィンゴ糖脂質複合体の分画が細胞膜のサイトゾー ル表面にあるとか、またサイトゾール内においてタンパク質と 複合体を作っているのではないかという実験事実が、そのほと んどは間接的証拠ではあるが、提出され興味をもって注目され ている(18-20)。さらに、光学顕微鏡観察によって、細胞骨格夕 
not be cytosolic $(7,17)$. In this context, it is of interest to note that evidence has been presented, although mostly indirect, to suggest that a fraction of the complex glycosphingolipids would occur on the cytosolic surface of cellular membranes or even complexed to proteins in the cytosol (see e.g. 18-20). Whether the association of glycosphingolipids with cytoskeletal elements, that was observed by fluorescence microscopy, reflects a cytoplasmic disposition of the lipids or a mere lining up of glycosphingolipid containing vesicles along the cytoskeleton remains to be resolved $(21,22)$. Finally, it has been observed that glycosphingolipids are not homogeneously distributed over the membrane(11), which is most likely a consequence of the capability of glycosphingolipids to form intermolecular hydrogen bonds. It has been proposed that glycosphingolipid microdomain formation is part of the mechanism by which epithelial cells sort components destined for the apical surface from basolateral membrane constituents(12). However, the existence of such microdomains in the sorting organelles, the trans Golgi network and the endosomes, remains to be demonstrated.

\section{B-2. Phosphoinositides}

PI is synthesized at the cytoplasmic surface of the ER membrane. From there, it is distributed over all intracellular organelles, including those that are not connected by vesicular transport. This suggests that PI can be transported by non-vesicular means, possibly by a transfer protein. In the latter case a fraction of the PI would exist as a PI-protein complex in the cytosol, indications for which have been obtained(23). The further glycosylation of PI to form the GPI anchor and the attachment of the anchor to the protein are thought to occur in the ER, although the distribution of free anchors over the various membranes has not been characterized(10). In connection with its function at the plasma membrane PIP and $\mathrm{PIP}_{2}$ would be expected to be present in the cytoplasmic leaflet of the plasma membrane. In erythrocytes all PIP and $80 \%$ of the PIP $_{2}$ was inaccessible from the outside(24). Phosphorylation of PI to yield PIP and PIP $_{2}$ has long been thought to be limited to the plasma membrane. However, evidence has been presented that these polyphosphoinositides can also be synthesized in the ER (25), the nuclear envelope(26), and even in the nuclear matrix (27). In support of this, the respective phosphoinositide kinases have been isolated from nuclear matrix fractions(9). The existence of a phosphoinositide signal transduction cascade in the nucleus was corroborated by the recent discovery in the nucleus of a specific subtype of the PIP- and PIP $_{2}$-specific phospholipase $C(28)$, and protein kinase $C(9)$.

\section{Morphological Localization of Glycolipids C-1 General}

Our present knowledge on the cellular and subcellular distribution of glycolipids has been obtained mainly by bio-
ンパク質にスフィンゴ糖脂質が会合していることが示されてい るが、それは糖脂質の細胞質内における特異的分布を反映して いるのか、あるいは細胞骨格タンパク質に沿って分布している 小胞中に存在するスフィンゴ糖脂質をただ単に検出しているの かどうかについては明かではない $(21 、 22)$ 。最後に、スフィン ゴ糖脂質は、膜上に均一には分布していないことが観察されて いる(11)。それは、分子間水素結合を形成しうるという、ス フィンゴ糖脂質の性質に起因する必然的な結果である可能性が 高い。その結果、糖脂質がクラスターを形成したミクロドメイ ンが形成され、これが上皮細胞における、頂端側の膜成分と側 面や低面の細胞膜の膜成分とを仕分けする機構であるとの仮説 が提出されている(12)。しかし、選択輸送されている細胞内小 器官やトランスゴルジネットワークとかエンドソームにおいて スフィンゴ糖脂質のミクロドメインの存在は、まだ明らかにさ れていない。

\section{B-2. フォスフォイノシタイド}

PIは、小胞体膜の細胞質側表面で合成される。PIはそこか ら全ての細胞内小器官に輸送され、そこには小胞の輸送経路と は無関係な細胞内小器官も含まれる。このことは、PIが小胞以 外の手段、おそらく輸送タンパク質によって輸送されることを 示唆している。後に、PI分画を解析したところ、PI-タンパク質 複合体が見いだされたことから、PIはサイトゾール内において タンパク質と複合体を形成して存在していることが明かとなっ た(23)。PIへの糖付加によるGPIアンカー形成やタンパク質への アンカーの結合は、小胞体で行われていると考えられている。 しかし、種々の膜上でのフリーのアンカーの分布については、 十分には明らかにされていない(10)。PIPやPIP 2 は、形質膜にお けるそれらの機能との関連て、形質膜の細胞質側に存在すると 予想される。赤血球において、PIPの100\%およびPIP,の80\%は細 胞外からは検出されなかった(24)。PIPと $\mathrm{PIP}_{2}$ を産生するPIのリ ン酸化は、長い間形質膜に限られて行われているものと考えら れてきた。しかし、これらポリフォスフォイノシタイドの生合 成が、ER(25)、核外膜(26)および核基質(27)においても認められ るという報告がなされた。その報告を支持するものとして、そ れぞれのフォスフォイノシタイドキナーゼが核基質画分から単 離された(9)。核内にフォスフォイノシタイド情報伝達カスケー ドが存在するということは、核内でPIPやPIP 特異的なフォス

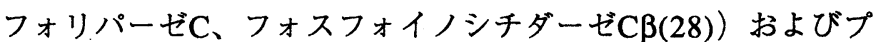
ロテインキナーゼC(9)が発見されたことによって一層強まっ た。

\section{C. 糖脂質の形態学的分布 C-1. 概論}

我々が知り得る糖脂質の細胞および細胞内分布について は、主に生化学的方法によって得られたものである。今日ま て、、顕微鏡レベルでの脂質分子の細胞内分布の解析は、光学顕 
chemical methods. Until recently, the subcellular distribution of lipid molecules at the microscopic level has been limited mainly to light microscopy due to the use of fluorescent lipid analogues and fluorescently labeled antibodies(29-33). This is in sharp contrast with the subcellular distribution of proteins where biochemical data are combined extensively with localization studies at the light microscopic level and especially at the electron microscopic level. Localization of proteins by EM (34-36), first by enzyme-cytochemical techniques and later on by immuno-labeling techniques using specific antibodies in combination with secondary antibodies coupled to alkaline phosphatase or horse-radish peroxidase, secondary antibodies coupled to ferritin or the immunogold technique, have contributed much to our present knowledge in cell biology. Immunocytochemical localization techniques have revealed the subcellular distribution and the various transport routes of many proteins. Only few studies on the subcellular localization of lipid molecules by EM have been reported(32, 37-41). The main reason for this has been the lack of reliable and reproducible methods for immunolocalization of lipid molecules at the electron microscopic level. Such methods should meet the same criteria required for protein localization i.e., the antigenicity should be maintained during the whole procedure, the antigens must be immobilized instantaneously so that they can not relocate, the antigenic site must be accessible for the antibody, and the cellular morphology must be excellent in order that intracellular structures can be identified. Proteins can be fixed by aldehydes without severe loss of antigenicity in many cases. Lipids, however, are not immobilized by routine fixatives. This causes their extraction when the tissue is dehydrated with organic solvents during embedding procedures. Also with cryoultramicrotomy, the very successful method with respect to immunolocalization of proteins, lipid molecules are not very well preserved and are extracted or relocated during section thawing, which will give unreliable immunolocalization results afterwards(42). The preparation methods for the localization of lipid molecules can be divided in two groups i.e., pre-embedding labeling and post-embedding labeling. In principle preembedding labeling techniques allow the detection of cell-surface located antigens whereas with post-embedding techniques both cell-surface and intracellularly located antigens can be detected. The aim of this minireview is to try to give the reader some idea of the possibilities of modern immuno-electronmicroscopical techniques with respect to the immuno-localization of glycolipids at the electron microscopic level.

\section{C-2. Pre-embedding Labeling Techniques}

Cells, that have antigenic epitopes on lipid molecules exposed to the extracellular environment, can be labeled with primary antibody and subsequently with a probe for detection at the EM level. After labeling of the cells they have to be further processed for EM observation. Labeled cells can either be
微鏡に限られていた。というのは、蛍光標識脂質アナログとか 蛍光標識抗体を用いた解析であったからである(29-33)。このこ とは、タンパク質の細胞内分布に関する研究と著しく対照的で ある。タンパク質の場合、細胞内分布に関する生化学的解析結 果は、光顕および電顕観察による分布の研究と強く結ばれてい る。電子顕微鏡におけるタンパク質の分布解析は、最初酵素細 胞化学的手法により行われた。その後、解析したいタンパク質 に対して特異的一次抗体を反応させ、続いてアルカリホスファ ターゼとか西洋ワサビ由来ペルオキシダーセ標識二次抗体、さ らにフェリチンや免疫金粒子を標識した二次抗体によって検出 するという免疫細胞染色が用いられるようになった。こうした ことから、タンパク質の細胞生物学的解析が進み、その情報も 増大している。このような免疫細胞化学的手法によって、多く のタンパク質の細胞内分布や、いろいろの輸送経路に携わる夕 ンパク質の局在が解明された。しかし、電子顕微鏡を用いた脂 質分子の細胞内分布について解析した報告は、極めて少ない(32 、37-41)。その主な理由として、電子顕微鏡による脂質分子の 解析において、信頼性と再現性の高い免疫学的手法がないため であった。脂質分子の分布解析のためには、タンパク質で得ら れたような信頼すべき方法の確立が必要である。すなわち、試 料作製過程において抗原性がよく保持されていること、抗原は 再分布することなく瞬時に固定されること、抗原部位は抗体に よって十分に認識されること、さらに、細胞形態は極めて良く 保持されその微細構造が明瞭であること、等である。タンパク 質は、多くの場合、その抗原性の極端な損失なしにアルデヒド で固定される。ところが、脂質は、通常の固定方法ではうまく 固定できない。組織の包埋過程に用いる有機溶媒の脱水時に、 組織内の脂質が包埋中に溶出されてしまう。また、凍結超薄切 片作成装置は、タンパク質の免疫学的手法による分布の解析に は優れた方法であるが、脂質分子では十分に分子が保持されな い。それは、超薄切片の解凍過程に脂質分子が溶出したり再分 布したりするためである。このことから、脂質分子の免疫学的 手法によって得られた分布の観察結果には、信頼性がなかった (42)。脂質分子の細胞内分布の解析方法は、次の二種類に大別 される。それは、抗体による pre-embedding と post-embeddingで ある。原則として、pre-embeddingでは細胞表面に分布している 抗原の検出に用いられるが、 post-embeddingでは細胞表面と細 胞内に分布する抗原の両方が検出できる。このミニレビューの 目的は、電子顕微鏡レベルにおける免疫学的手法を用いた糖脂 質分子の分布の解析に関して、現在の免疫電顕技術の可能性に ついての情報を提供することにある。

\section{C-2. Pre-embedding標識技術}

細胞膜外に露出した脂質分子上に抗原エピトープがある細 胞では、一次抗体で標識することができ、さらに電子顕微鏡で 検出するためのプローブにより標識可能である。細胞を標識し た後、その細胞を電子顕微鏡観察用に処理する。標識された細 
processed for conventional plastic embedding(43-45), for freeze-etching $(46,47)$, or for label-fracture(48). Even when antigens have their epitopes on the outer surface of the plasma membrane, labeling might be prevented due to steric hindrance. When the epitope is buried within the outer lipid monolayer or covered by carbohydrate chains or proteins the epitope might not be accessible for the antibody(49). Although thin sections of labeled and plastic embedded cells give some information on the cell-surface distribution of antigens, only freeze-etching and label-fracture reveal the distribution in the plane of the bilayer. When using this technique one has to keep in mind that lipid molecules can not be fixed by routine aldehyde fixations. Therefore the observed distribution does not necessarily reflect the in vivo distribution. Especially during incubations with primary and secondary antibodies artificial clustering of molecules can be induced $(32,46,50)$. The main limitation of preembedding techniques is obvious. Only cell-surface located antigens on single cells or on cell monolayers can be labeled. To circumvent this limitation, cells can be permeabilized before labeling. An exciting development are the various controlled procedures for the selective permeabilization of the plasma membrane (e.g. 51, 52). Still, these procedures have to contend with rearrangements of lipids, and the fact that labeling is still limited to epitopes exposed to the cytoplasm. Subcellular localization of lipid molecules without the fundamental drawbacks of pre-embedding labeling can only be obtained by postembedding labeling.

\section{C-3. Post-embedding labeling}

The intracellular localization of lipid molecules at the EM level has been hampered in the past by the lack of reliable and reproducible methods for post-embedding labeling. The main problem has been the immobilization of lipids during the embedding procedure. Several methods have been used with great success for the immuno-localization of proteins. Cryoultramicrotomy has been the method of choice for protein localization studies with the immunogold technique $(35,36)$. Tissues or cells are fixed by aldehyde fixation, cryoprotected with 2.3 $M$ sucrose, and frozen in liquid nitrogen. Ultrathin frozen sections are cut at around $-100^{\circ} \mathrm{C}$. The frozen sections are thawed and subsequently labeled with the immunogold technique. Whereas excellent results have been obtained for the localization of proteins this holds not true for the localization of lipid molecules. This problem is mainly due to the impossibility to immobilize lipids by aldehyde fixation. We have shown that lipid-rich structures such as lamellar bodies in alveolar type II cells of the lung, which consist for $90 \%$ of lipids and only $10 \%$ of proteins, are not preserved in ultrathin cryosections(42). The lamellar bodies probably dissolve during section thawing. In the past we have made some attempts to localize the Forssman glycolipid on ultrathin cryosections of Madin Darby canine kidney(MDCK) cells. Immunogold labeling was irreproduc-
胞は、通常の樹脂包埋(43-45)、フリーズエッチング(46-47)およ び割断法(48)のいずれかの過程をへて観察される。しかし、形 質膜の外に抗原がある場合でも、分子の立体障害のためにすべ ての抗原が標識されるわけではない。また、抗原エピトープが 外側の脂質層に埋もれているとか、他の糖鎖とかタンパク質に よって覆われている場合には、そのエピトープは抗体によって 標識されない(49)。標識され、樹脂包埋された細胞の薄切片で の観察からは、抗原の細胞表面上の分布について幾つかの情報 が得られるが、フリーズエッチング法とか割断法では、脂質二 重膜における水平方向の抗原分布についての情報が得られる。 上記のいずれの方法を行うにしろ、脂質分子は、通常のアルデ ヒド固定では固定されないことを十分に心得ておかなければな らない。それ故に、観察された分布はin vinoでの分布を必ずし も反映していない。特に、一次および二次抗体を反応させてい る間に分子のクラスターが人為的に生ずる可能性がある(32、

46、50)。いずれにしろ、脂質分子のpre-embedding標識技術に は限界があるが、浮遊細胞あるいは接着性細胞における細胞表 面は、この方法で標識することができる。この限界を突き破る ためには、標識前に細胞の透過性を增すことである。形質膜の 選択的透過に関する様々な制御された方法の開発が不可欠であ る(51、52)。これまでのところ、いずれの方法でも細胞内にお ける脂質の再分布が生じてしまう。事実、標識される脂質は、 いまだ細胞質に露出したエピトープに限られている。脂質分子 の細胞内分布は、 pre-embedding標識の本質的な短所のないpostembedding標識によってのみ得ることができる。

\section{C-3. Post-embedding標識}

電子顕微鏡による脂質分子の細胞内分布の解析は、信頼す べきまた再現性のある post-embedding標識法がなかったため に、過去、妨げられてきた。主たる問題点は包埋過程において いかに脂質分子を固定するかということである。これまで、幾 つかの方法が、タンパク質の免疫学的分布解析において功を奏 している。超薄切片作製は、タンパク質のイムノゴールド法に よる分布解析には最も良い方法である(35、36)。組織および細 胞を、アルデヒド固定し、2.3 M ショ糖で凍害防止を行い、そ の後液体窒素で凍結する。超薄凍結切片は、約 $-100^{\circ} \mathrm{C} て ゙$ 作製す る。作製した凍結切片を解凍し、引き続いてイムノゴールド法 により標識する。この方法によって、タンパク質の場合、極め て良好な結果が得られているが、脂質分子の場合では良好な結 果は得られていない。この問題は、脂質分子の固定にアルデヒ ドが適していないことによる。我々は、以下の結果を得た。す なわち、肺の肺胞II型細胞の層板小体( $90 \%$ が脂質で10\%がタン パク質)のような脂質に富んだ構造は、超薄切片で解析したとこ ろ、脂質は保持されない(42)。この結果は、たぶん凍結切片の 解凍の間に層板小体にある脂質が溶出したためであると考えら れた。これまで、我々は、超薄切片によるMDCK細胞のフォル スマン糖脂質の分布について解析することを試みてきた。イム 
ible and sparse labeling was found over membranes. Often we observed gold labeling spread over the cytoplasm and the nucleus(41). This labeling was probably due to extraction and relocation of the Forssman glycolipid during section thawing and the immuno-incubations. Other embedding techniques such as low temperature embedding in LR-White or LR-Gold have not been very successful in our hands with respect to the preservation of lipids (lamellar bodies were extracted).

Recently we have combined freeze-substitution in combination with low temperature embedding in Lowicryl HM20 with aldehyde-fixed and cryoprotected material as an alternative method for post-embedding immunolabeling and the preservation of lipid-rich structures $(41,42)$. Freeze-substitution is a dehydration method that can be combined with plastic embedding. Due to the dehydration at very low temperature ($90^{\circ} \mathrm{C}$ ), the extraction of lipids, which is a serious problem during dehydration at room temperature, is virtually excluded. Several studies have shown biochemically that most lipids are retained after freeze-substitution(53-55) and that lipid-rich structures and even pure lipidic structures are very well preserved $(42,56)$.

\section{C-4. Immunogold Localization of Forssman Glycolipid}

For the development of our method for the immunogold localization of antigenic lipids, we have chosen the five-sugar Forssman glycolipid in epithelial MDCK cells as a model system(41). Transwell filters with a confluent monolayer of MDCK cells were fixed with $2 \%$ paraformaldehyde in $0.1 \mathrm{M}$ Pipes buffer(pH 7.2), cryoprotected and frozen in liquid nitrogen when cryoprotected in $2.3 \mathrm{M}$ sucrose, or in liquid propane when cryoprotected in $30 \%$ glycerol. Frozen samples were freeze-substituted at $-90^{\circ} \mathrm{C}$ in methanol containing $0.5 \%$ uranyl acetate, embedded in Lowicryl HM20 and polymerized at $45^{\circ} \mathrm{C}$ by UV-light in a Reichert CS-auto freeze-substitution unit (Leica Aktiengesellschaft, Wien, Austria). Ultrathin sections were labeled with a monoclonal antibody against Forssman glycolipid(generous gift of Dr. A. Sonnenberg, 29) and protein A-gold (for more detailed information on substitution and labeling procedures see ref. 41). Loss of Forssman glycolipid after freeze-substitution was determined by radio-immunolabeling of glycosphingolipids after separation of lipid extracts of MDCK cells by thin layer chromatography(TLC). This reliable method showed that the Forssman glycolipid had been completely retained during the freeze-substitution procedure(103 $\pm 15 \%$ ).

First of all, a good ultrastructural preservation of the sample was observed. In addition, the labeling was abundant, while at the same time the background was low. The latter was clear from the fact that the Forssman glycolipid was exclusively membrane-associated, the nuclear matrix was clean, and from the fact that some organelles, mitochondria and peroxisomes, were not labeled. The plasma membrane was
ノゴールド標識では再現性にそしく、また膜上に極めてまばら にしか標識されていなかった。さらに、その標識がしばしば細 胞内や核内にもまばらに存在していた(41)。これらは、切片の 解凍とか免疫標識のための抗体反応の間にホルスマン糖脂質の 溶出もしくは再分布によって生じたと考えた。別の包埋法とし てLRーホワイトやLR-ゴールドによる低温包埋による方法におい ても脂質の保持は十分ではなかった。すなわち、層板小体の脂 質は、ほとんど全て溶出されてしまった。

最近、我々は、post-embeddingの免疫標識と脂質に富む構 造の保持のための別の方法として、アルデヒド固定して凍害防 止処理を行った試料を、凍結置換法と低温包埋剂ロイクリル

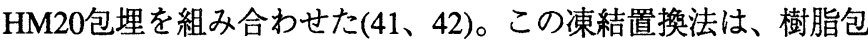
埋と組み合わせることができる脱水法の一つである。また、極 めて低温 $\left(-90^{\circ} \mathrm{C}\right)$ で脱水するため、これまでのように常温脱水の 間に生じていた脂質の溶出を実際上無視できる。凍結置換後の 試料中には、ほとんど全ての脂質がよく保持されていたという ことが生化学的解析によって示された(53-55)。さらに、脂質に 富んだ構造とか脂質のみから成る構造も極めてよく保持されて いることが判明した $(46 、 56) 。$

C-4. フォルスマン糖脂質のイムノゴールドによる分布

脂質抗原のイムノゴールドによる分布解析のための方法を より一般的なものとするために、モデル系として上皮性MDCK 細胞の5糖で構成されているフォルスマン糖脂質を選択した。十 分に培養生育したMDCK細胞を、2\%パラホルムアルデヒド-0.1 $\mathrm{M}$ ピペス緩衝液( $\mathrm{pH}$ 7.2)で固定した。次に、2.3 Mショ糖で凍害 防止を行う場合には液体窒素で凍結し、また30\%グリセロール を使用する場合は、液体プロパンで凍結した。凍結試料は、 $90^{\circ} \mathrm{C}$ の $0.5 \%$ 酢酸ウランを含むメタノール中で凍結置換を行っ た。続いて、ロイクリルHM20に包埋し、ライヒェルトCS自動 凍結置換装置(Leica Aktiengesellschaft, Wien, Austria)の紫外光 でー45ㄷにてて重合させた。作製した超薄切片は、フォルスマン 糖脂質特異的なモノクローナル抗体(A. Sonnenberg 博士より供 与された、29)と反応させ、続いてプロテインA-ゴールドで標識 した(置換法および標識法の詳細については文献41を参照)。凍 結置換後のフォルスマン糖脂質の損失程度については、凍結置 換したMDCK細胞からの抽出した脂質をTLCで分離した後、放 射性免疫標識により行った。その結果、この方法の過程におい てフォルスマン糖脂質は、完全に細胞に残存していることが示 された $103 \pm 15 \%)$ 。

まず第一に、超微細構造は十分に保存されていることが明 かとなった。標識の程度は十分であり、と同時にバックグラウ ンドは低かった。というのも、フォルスマン糖脂質のほとんど は膜に会合して分布しており、核基質、ミトコンドリアおよび ペルオキシゾームには全く標識は全く認められないからであ る。形質膜は強く標識された(図1)。フォルスマン糖脂質の膜分 布濃度について、細胞の頂端部位の濃度は基低外側部位に比べ 
densely labeled(Fig. 1). From a calculation of the membrane density, labeling on the apical domain was 1.4-1.6 times higher than on the basolateral domain. Model studies will have to prove whether the labeling density can be extrapolated to the surface density of the Forssman glycolipid on the two cell surfaces. This difference in labeling density is in agreement with the general enrichment of glycosphingolipids on the apical surface of epithelial cells. The presence of the diffusion barrier between the two plasma membrane domains in the external bilayer leaflet(12) assigns the difference in density to this external leaflet, the cell surface. Indeed, Forssman glycolipid is accessible for antibodies from the outside of the cell $(30,32,44$, $50,57)$. In agreement with the earlier studies at the light microscopical level $(50,57)$, the tight junction between neighboring cells did not allow diffusion of Forssman glycolipid from one cell to the next, a property that could now also be established for the basolateral side of the tight junction.

Apart from the plasma membrane, also endosomal membranes were heavily labeled, whereby a significant fraction of the label was over the endosomal/lysosomal contents. As could be expected from the known location of the glycosyltransferases in the Golgi complex, labeling of Golgi membranes was consistently observed(Fig. 1). Rather unexpected was the fact that always some gold particles were observed over the nuclear membrane, although the density over the nuclear membrane was 10 -fold lower than over the plasma membrane. This finding implies that a transport pathway for Forssman from the Golgi to the ER must exist. This could be a direct return pathway but it could also reflect vesicular traffic from the plasma membrane and endosomal membranes to the ER. The low level of Forssman glycolipid in the ER could imply inefficient return traffic or, alternatively, it could mean that Forssman glycolipid is preferentially transported out of the $\operatorname{ER}(7$, 13).

Although the possibility that some Forssman glycolipid would be oriented towards the cytoplasm can not be completely excluded, non-vesicular transport routes for Forssman are unlikely from the fact that, in that case, it would be difficult to see how the mitochondria and peroxisomes could remain Forssman negative.

\section{C-5. Subcellular Distribution of PIP ${ }_{2}$ by Immuno-EM}

Because of the importance of especially the glycophospholipid PIP $_{2}$ in signal transduction and because not much is known about its subcellular distribution, we have made a first attempt to extend the excellent and reliable immuno-EM localization of Forssman glycolipid to reveal the subcellular distribution of PIP ${ }_{2}$. For this study we have made use of two wellcharacterized anti-PIP ${ }_{2}$ antibodies. The first, monoclonal $\mathrm{KT} 10$, is an $\mathrm{IgG} 2_{\mathrm{b}}$ subclass that did not react with any protein in a Western blot analysis of 3T3 cells, did not react with DNA from salmon testis in a dot blot analysis, and was specific for
て1.4-1.6倍高かった。この研究で、標識濃度そのものが頂端部 位とそれ以外の部位という二つの細胞表面上のフォルスマン糖 脂質の濃度に相当しているかどうかを明らかにする必要がある であろう。事実、標識濃度の膜上での違いは、上皮細胞の頂端 部位において一般的にスフィンゴ糖脂質が多量に存在している というこれまでの知見と良く一致している。脂質二重膜の外側 における二つの形質膜ドメイン間に、拡散に抵抗性のバリアー が存在(12)する事によって、細胞表面である外膜におけるドメ イン間の濃度の差が生じる。事実、フォルスマン糖脂質は細胞 の外側から抗体によって認識される(30、32、44、50、57)。初 期の光学顕微鏡による結果と一致して、隣接細胞間に形成され る強固な結合を介したフォルスマン糖脂質の細胞から隣接細胞 への移行はないということである。この性質は、基低外側部位 における強固結合にも当てはまるものである。

形質細胞膜以外には、細胞質内の膜系にも標識が認めら れ、それはエンドソームやリソゾームの膜を強く標識した。ま た、ゴルジ体には糖転移酵素が存在していることが知られてお り、その事から十分に予測されたことであったが、ゴルジ膜に も相応の標識が観察された(図1)。予想に反し、有意の金コロイ ド粒子が核膜全体にわたって存在することが観察された。ただ し、核膜上の標識濃度は、形質膜にくらべて10倍以上低かっ た。この事実は、ゴルジから小胞体へのフォルスマン糖脂質輸 送経路の存在を示唆する。それは、逆にリターン経路であるか もしれない。また、形質膜およびエンドソーム膜から小胞体一 の小胞輸送の存在を反映しているかもしれない。小胞体におい てフォルスマン糖脂質が低濃度であることは、リターン経路で ある可能性は低く、むしろフォルスマン糖脂質は、小胞体から 選択的に輸送されていることが想定される(7、13)。フォルス マン糖脂質が、細胞膜上で細胞質の方向に向かって存在してい るという可能性は完全には否定できないけれども、フォルスマ ンの小胞を介さない輸送経路というのは実際にはありそうもな い。もしその様な経路が存在するとすれば、ミトコンドリアと かペルオキシゾームになぜフォルスマン糖脂質が観察されない のか説明できない。

\section{C-5. 危疫電顕によるPIP 2 の細胞内分布}

情報伝達経路において、糖リン脂質PIP $P_{2}$ は極めて重要であ るり、その細胞内分布についてはほとんど知られていないの で、我々は、フォルスマン糖脂質解析に用いた優れた免疫電顕 法をその解析に応用した。この研究には、2つの十分に性状の明 かな抗PIP 2 抗体を用いた。一つは、KT10と名付けられたモノク ローナル抗体であり、抗体サブクラスはIgG2bである。この抗 体は、3T3細胞から得たいずれのタンパク質ともウエスタンブ ロット解析において反応せず、サケ精巣のDNAもドットブロッ 卜解析で反応しなかった。そして、TLC免疫染色において、 PIP、PIおよびPIP の頭部、すなわち親水性ハプテンである $\mathrm{IP}_{3}$ と は全く反応せず、PIP 2 のみ特異的に反応した $(58)$ 。もう一つの抗 C1992 FCCA (Forum: Carbohydrates Coming of Age) 


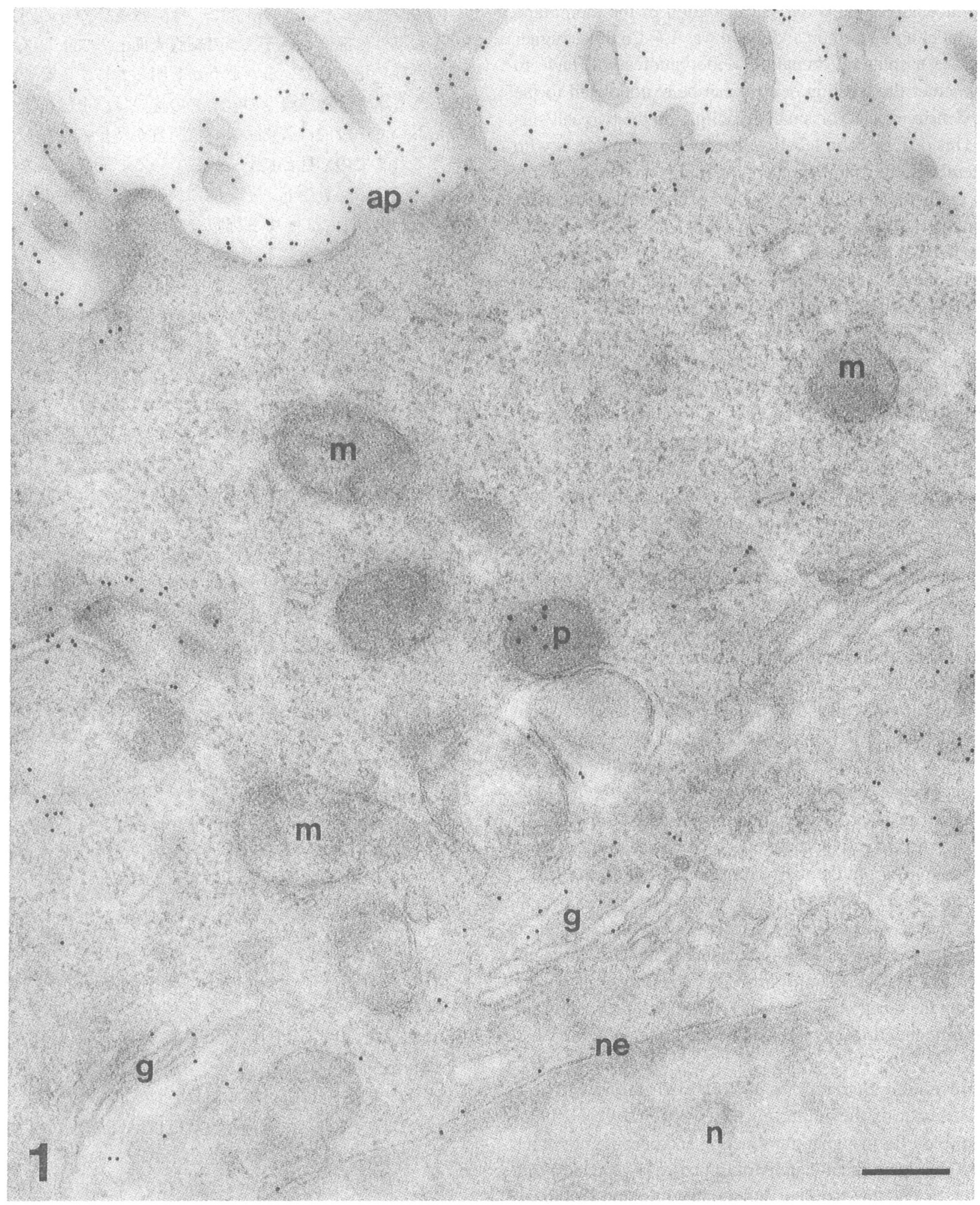

Fig. 1. MDCK cells grown on filters were fixed with $2 \%$ paraformaldehyde, cryoprotected with $2.3 \mathrm{M}$ sucrose, and frozen in liquid nitrogen. Frozen samples were freeze-substituted at $-90^{\circ} \mathrm{C}$ in methanol containing $0.5 \%$ uranyl acetate and embedded in Lowicryl HM20 at $-45^{\circ} \mathrm{C}$. Ultrathin sections were double-labeled with anti-Forssman ( $10 \mathrm{~nm}$ protein A-gold) and anti-catalase $(15 \mathrm{~nm}$ protein A-gold). The apical plasma membrane(ap) is densely labeled. Intracellular Forssman labeling is observed in the Golgi complex(g), the nuclear envelope (ne), and on various membrane structures in the cytoplasm. A catalase-positive peroxisome(p), mitochondria(m), and the nuclear matrix(n) are negative for Forssman labeling. Bar $=200 \mathrm{~nm}$. 
$\mathrm{PIP}_{2}$ in TLC-immunostaining without cross-reactivity with PIP, PI, or the free headgroup of PIP ${ }_{2}$, the water-soluble hapten inositol 1,4,5-trisphosphate $\left(\mathrm{IP}_{3}\right)(58)$. The second antibody, monoclonal AM-212, is an IgG3 that is specific for $\mathrm{PIP}_{2}$ by ELISA and in a complement dependent liposome lysis assay, did not cross-react with PIP or PI, but showed considerable reactivity with $\mathrm{IP}_{3}(59)$. The antibodies were applied to ultrathin sections of freeze-substituted and Lowicryl HM20 embedded MDCK cells, which was followed by $15 \mathrm{~nm}$ protein A-gold as described before(41). Monoclonal antibody KT10 labels both the apical and the basolateral domain of the plasma membrane (Fig. 2). Beside this plasma membrane-associated labeling also intracellular labeling is observed. In the cytoplasm, both gold-label associated with intracellular membranes as well as label free in the cytosol are observed. The antibody showed an unexpectedly high labeling density over the nuclear matrix. The labeling is not homogeneously distributed over the nuclear matrix but seems to have a preference for heterochromatin.

The labeling pattern of monoclonal antibody AM-212 partially overlaps with that of monoclonal antibody KT10(Fig. 3). Again both the apical and the basolateral domain of the plasma membrane are labeled, although the labeling density with AM-212 is significantly higher than with KT10. Intracellular labeling in the cytoplasm is very low and seems not to be above background levels. Like KT10, antibody AM-212 labels the nuclear matrix specifically, but the labeling density is lower and the labeling does not seem to have a preference for heterochromatin. In fact, nuclear staining at the light microscopy level has been published with this antibody for rat brain cells and arguments have been presented against $\mathrm{IP}_{3}$ being the antigen(60).

Control experiments in which the primary antibody was omitted showed essentially no gold labeling. To exclude the possibility that both antibodies against $\mathrm{PIP}_{2}$ cross-react with DNA and/or RNA both antibodies were preincubated with an excess of a purified DNA/RNA mixture. The preadsorbed antisera gave no significant reduction in the amount of label over the nuclear matrix.

It is not unexpected that both anti-PIP ${ }_{2}$ monoclonals labeled the plasma membrane, and it would be difficult to see how in the case of AM-212 this could be due to cross-reactivity with $\mathrm{IP}_{3}$ which could be present in the cytosol. The major difference between the labeling patterns obtained with the two antibodies was that KT10 abundantly labeled the nuclear matrix, especially the heterochromatin, and that AM-212 gave a disperse but low level of labeling over the nuclear matrix. A most interesting possibility would be that the antigen recognized by KT10 in the nuclear matrix is non-membrane-associated PIP $_{2}$. Because of its hydrophobic tails PIP $_{2}$ must be complexed to something else, most likely a protein, on the surface of which it must be partially buried in some hydrophobic cleft.
体は、AM-212と名付けられたモノクローナル抗体であり、その 抗体サブクラスはIgG3である。この抗体は、ELISAおよび補体 依存性のリポソーム溶解試験からPIP 2 特異的であった。すなわ ち、PIPおよびPIには反応しなかったが、 $\mathrm{IP}_{3}$ とは交叉反応した (59)。凍結置換し、ロイクリルHM20で包埋されたMDCK細胞の 超薄切片上でこれらの抗体と反応させ、前に述べたように $15 \mathrm{~nm}$ のプロテインA-ゴールドで検出した(41)。KT10抗体は、MDCK 形質膜の基低外側部位と頂端部位の両方を標識した(図2)。さら にこの抗体は、形質細胞膜上だけでなく細胞質内をも標識して いた。金コロイド粒子は、細胞内膜に関連して存在したが、同 様にフリーの状態でサイトゾール中にも観察された。また予想 に反し、この抗体は、核基質を強く標識していた。その分布 は、均一ではなく、異質染色質に選択的であると思われた。

AM-212抗体の標識パターンは、KT10の一部と重なる(図 3)。この抗体も細胞の頂端部位と基低外側部位の両方を標識し たが、その濃度はKT10より遙かに高かった。ところが、細胞質 内の標識の染色程度は極めて低く、バックグラウンドと同等で あった。しかし、この抗体は、KT10と同様に核基質を特異的に 標識したが、その標識の程度は低く、また異質染色質特異的と は認められなかった。事実この抗体は、光学顕微鏡レベルで ラット神経細胞の核を染色するということが示されており、さ らに主たる抗原はIP ${ }_{3}$ でるといわれている(60)。

一次抗体なしのコントロール実験では、組織上に全くゴー ルド標識されない。PIP 特異的なこの二つの抗体がDNAやRNA とは交叉反応するということを除去するために、これら2つの抗 体を過剩量の精製DNA/RNA混液とあらかじめ反応させた。こ の吸収抗体は、核基質の標識の程度に何の変化も与えなかっ た。

二つの抗PIP 2 抗体が、形質膜を標識することは予め予期さ れたことである。また、AM-212の場合、サイトゾール中のIP との交叉反応性の結果、細胞膜を標識したとは考えにくい。二 つの抗体によって得た染色パターンの主な違いは、KT10が核基 質を、特に異質染色質を極めて強く標識したが、AM-212では核 内をまばらにしか標識せず、その程度も極めて低かったことで ある。この結果から得られた最も興味ある点は、KT10が反応し た核基質内の抗原は、非膜結合型のPIP ${ }_{2}$ ではないかということ である。通常、PIP 2 はその疎水末端でタンパク質のような他の 物質と複合体を形成している。また膜上では、膜の蹯水性亀裂 部位に埋もれたような状態にある。膜上のPIP 2 は、これらの抗 体で認識されるような状態で存在していると考えられるが、夕 ンパク質と複合体を形成しているPIP 2 は、KT10では認識される ものの、AM-212では認識されないのかもしれない。PIP 2 合成酵 素であるPIPキナーゼおよびPIP ${ }_{2}$ 加水分解酵素であるホスホイノ シチダーゼCが、細胞膜から遠く離れた核の内部基質に見いだ されたことは、この考え方を支持するものである(9、28)。 $\mathrm{PIP}_{2}$ の核内への情報伝達に関する機能的因果関係を実験的に得るに 


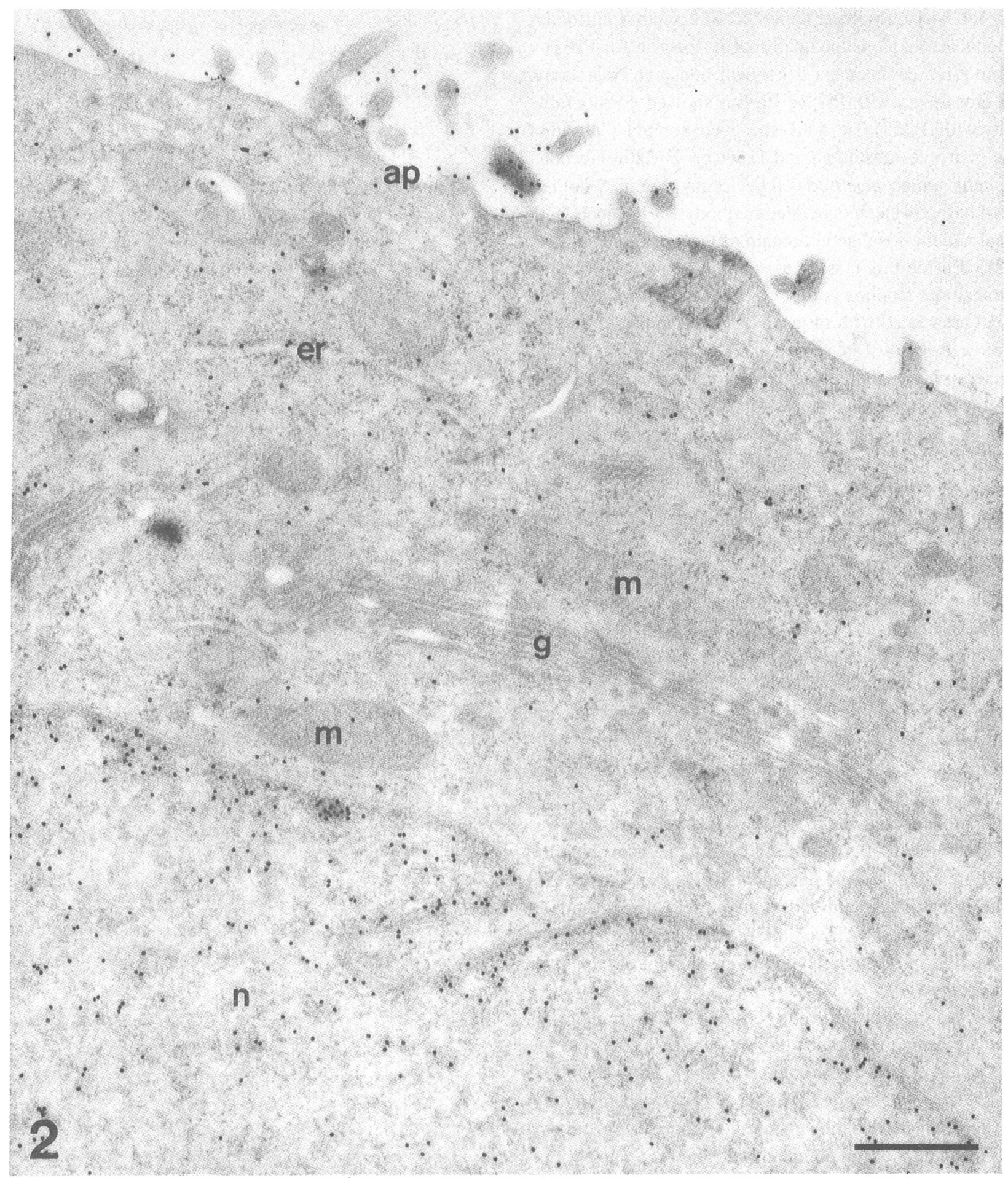

Fig. 2. Freeze-substituted and Lowicryl HM20 embedded MDCK cell as in Fig. 1 labeled with monoclonal antibody KT10 against PIP and $15 \mathrm{~nm}$ protein A-gold. Labeling for PIP $_{2}$ is observed at the plasma membrane(ap), at intracellular structures in the cytoplasm, such as endoplasmic reticulum(er), and small membrane structures, apparently free in the cytsol, and very abundantly in the nuclear matrix $(\mathrm{n})$, mostly associated with heterochromatin. Some labeling is observed over mitochondria $(\mathrm{m})$, which is probably due to background staining. Labeling for PIP ${ }_{2}$ is absent from the Golgi complex $(\mathrm{g})$. The very small gold is $5 \mathrm{~nm}$ gold coupled to bovine serum albumin, which has been taken up by the cells as a fluid-phase probe to label the endocytotic pathway. Bar $=500 \mathrm{~nm}$. 


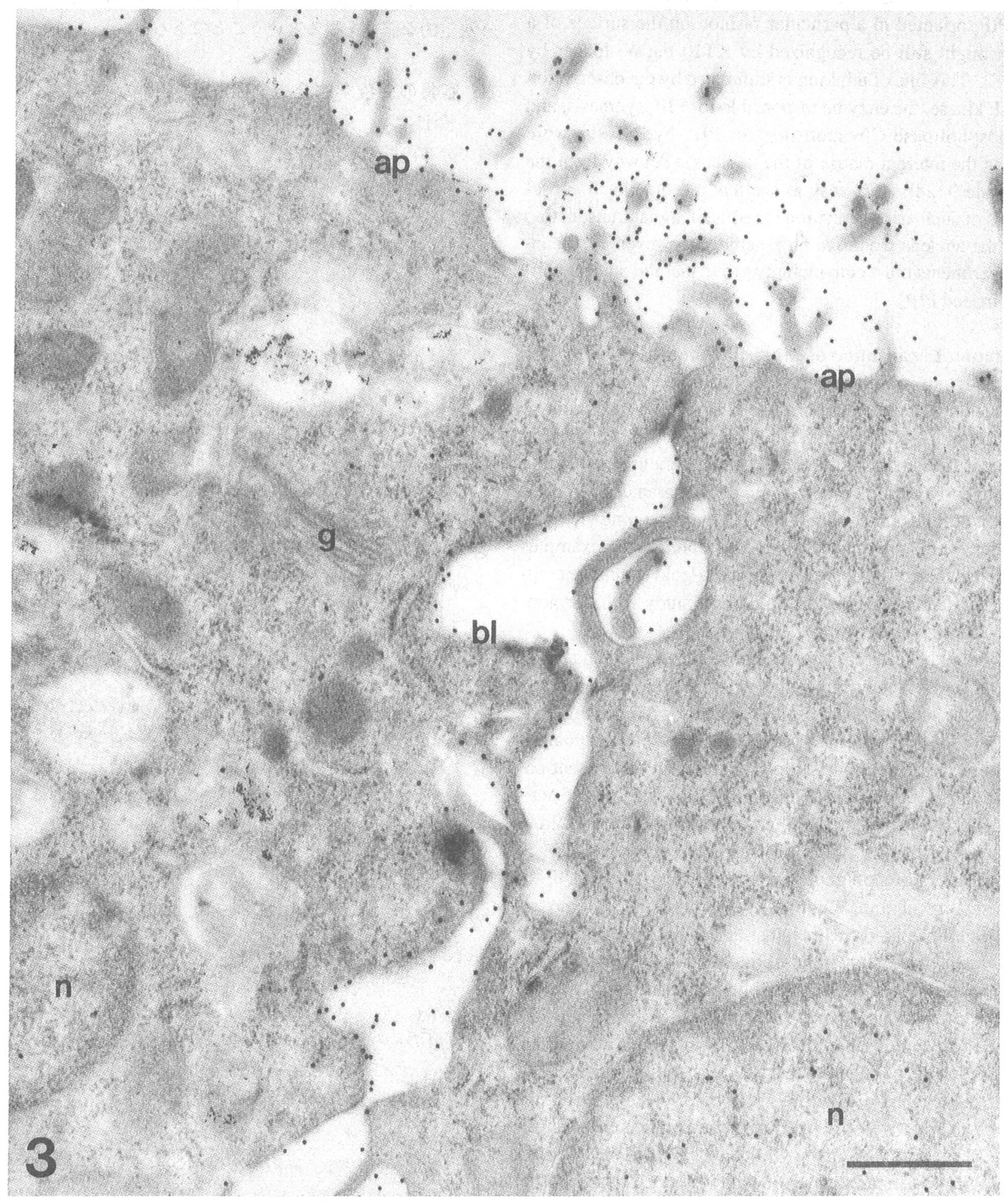

Fig. 3. An ultrathin section of the same MDCK cells as in Fig. 2, but now labeled with monoclonal antibody AM-212 and $15 \mathrm{~nm}$ protein A-gold. Both the apical(ap) and the basolateral(bl) plasma membrane are heavily labeled. Intracellular labeling over the cytoplasm is very low and seems not to be above background labeling. The Golgi complex(g) is negative for PIP $_{2}$ labeling. Again the nuclear matrix (n) is labeled, although not as abundantly as by KT10 and without a clear preference or heterochromatin. Bar $=200 \mathrm{~nm}$. 
Whereas PIP $_{2}$ at a membrane surface would be exposed in a way that it would be recognized by each of the two monoclonals, PIP $_{2}$ oriented in a particular fashion on the surface of a protein might still be recognized by KT10 but no longer by AM-212. This line of thinking is stimulated by the observation that PIP kinase, the enzyme responsible for $\mathrm{PIP}_{2}$ synthesis, and the phospholipase $\mathrm{C}$ responsible for $\mathrm{PIP}_{2}$ hydrolysis, were found in the internal matrix of the nucleus, i.e. away from the membrane $(9,28)$. It is easy to see that the functional consequences of such an organization in terms of signal transduction inside the nucleus would be far reaching. However, first, control experiments must convincingly prove that the nuclear antigen is indeed PIP $_{2}$.

\section{Immuno-Localization of Lipids: What's Next?}

It is now routinely possible to immuno-localize lipid molecules under the electron microscope with a resolution of about $20 \mathrm{~nm}$ in a highly reproducible fashion. The preparation method of freeze-substitution and low temperature embedding of aldehyde-fixed and cryoprotected cells guarantees complete retention of lipids in the sample, and at the same time yields an excellent overall morphology. Furthermore, in the examples provided in the present paper, the immuno-gold technique combined abundant labeling of the lipid under study with low nonspecific backgrounds.

It will be interesting to explore the quantitative potential of the method. It seems rather straight forward to study the linearity of the labeling in liposomal systems with varying concentrations of the antigenic lipid in an indifferent lipid matrix. However, one difficulty has been described in the present paper. The efficiency by which the lipid is recognized by the antibody may heavily depend on the environment in which the lipid is present. While one antibody efficiently recognized PIP $_{2}$ in the nucleus, a different antibody preferentially labeled PIP $_{2}$ in the plasma membrane. While this seems to be an extreme example where the lipid occurs either as a membrane component or in what is most likely a lipid-protein complex, it remains to be established how the efficiency of the lipid immuno-labeling on Lowicryl sections depends on the direct environment of the antigen in the various membranes and lipid-protein complexes.

A second point of interest will be to optimize the resolution of the technique. Clearly, one would like to address the question to what side of a membrane a certain lipid was oriented. At present it is unknown whether lipid molecules can reorient across a membrane profile at the surface of a Lowicryl section. If so, alternative methods will be required like selective membrane permeabilization, as discussed in the text. If not, it will be necessary to shorten the distance between the gold particle and the antigen which in the studies presented here still is more than the thickness of a membrane profile $(20 \mathrm{~nm}$ vs. $5 \mathrm{~nm})$ and which may cause folding of the protein A-gold-antibody
は、まだ多くの困難があることは明かである。しかしその一歩 として、基本的実験として、核内抗原が本当にPIP ${ }_{2}$ あるるとい う決定的な証拠を得るということであろう。

\section{D. 脂質の免疫学的分布の観察: 残された課題？}

今日では、免疫電顕の技術を用いて、20 nmの解像力で脂 質の分布の観察を再現性良く行うことができる。アルデヒド固 定と凍害防止した細胞を、凍結置換および低温包埋の方法を用 いることによって、作製した試料中に完全な形で脂質保持がな され、同時に、その形態学的にも極めてよく保持される。さら に、この論文で示したように、イムノゴールド技術は、非特異 的バックグラウンドが低く、脂質特異的標識が十分になされて いた。

この方法での定量性について検討することは興味ある点で ある。ある脂質の基質に、種々の抗原性を有する脂質を埋め込 んだリポソームを調製し、それを用いることで標識される程度 の直線性を検討することは、比較的容易であろう。しかし、ひ とつの困難な点がこの論文中に述べてある。すなわち、抗体と 脂質分子との反応効率は、脂質がどのような状態で存在してい るかということに大きく左右される。ある抗体は、核内のPIP ${ }_{2}$ を効率よく認識するのに、別の抗体は形質膜のPIP ${ }_{2}$ を選択的に 認識する。このことは、PIP 脂質が1つの膜成分であるのかタン パク質複合体として存在しているのかを明らかにする最も良い 実験例であると思われる。しかし、ロイクリル包埋して作製し た切片上において、脂質分子への免疫学的標識効率が、膜上と タンパク質複合体という分布環境の違いによってどのように依 存するのかは、明らかにされていない。

次に興味ある点は、技術的改良を加えて至適条件を見いだ すことである。明らかに、膜上で脂質がどちら側に向いている かという問題が残されている。現在のところ、脂質分子が、口 イクリル包埋の切片上でその配向を変えうるのか否かは明かで ない。もし、配向が変わるなら、既に述べてきたように、膜に 選択的な透過性を与える処理が必要となろう。もしそうでなけ れば、ゴールド粒子と抗原との距離をもっと短くして解析する 必要がある。というのは、この実験では、膜の厚さ $(5 \mathrm{~nm})$ に対 して用いたゴールド粒子 $(200 \mathrm{~nm})$ が大きすぎるために、また抗 体-プロテイン・ゴールド粒子複合体の折り曲がりによって、細 胞膜の内側に標識されたように見えてしまうからである。一次 抗体をFabフラグメントにし、これに直接ゴールト粒子を結合さ せた直接標識法は、極めてよい方法であると思われる。最後 に、膜上における種々の脂質を観察できるように、解像力を高 める必要がある。それによって、例えばゴルジ体の膜に存在す るような、スフィンゴ糖脂質のミクロドメインが細胞膜におい ても観察される可能性があるものと思われる。

原則として、どのような脂質抗原でも細胞内分布を解析す ることができる。これまでに非常に多くの抗脂質抗体が得られ 
complex across such a profile. Fab-fragments directly coupled to gold seem the most direct way to go. Finally, it is a challenge to improve the method to a level of resolution where one can study the lateral organization of the various lipids in the membrane. One fascinating question would be whether or not microdomains of glycosphingolipids can be visualized in the membrane of for example Golgi membranes.

In principle, the subcellular distribution of any antigenic lipid can be determined. Numerous anti-lipid antibodies have been isolated. Of course, every new lipid antigen-antibody couple will have to be characterized in terms of specificity of the antibody and efficiency of binding, while also the optimal conditions for efficient labeling of the antigen with a low nonspecific background must be worked out. Unique labeling patterns maybe obtained for the various lipids. They would be a nice pay-off for all the work that will have to be done.

\section{References}

1. Feizi, T. (1985) Nature 314, 53-57

2. Hirschberg, C.B., and Snider, M.D. (1987) Annu. Rev. Biochem. 56, 63-87

3. Hakomori, S.-i. (1990) J. Biol. Chem. 265, 18713-18716

4. Curatolo, W. (1987) Biochim. Biophys. Acta 906, 137-160

5. Schnaar, R.L. (1991) Glycobiology 1, 477-485

6. Kolesnick, R.N. (1991) Prog. Lipid Res. 30, 1-38

7. van Meer, G., and Burger, K.N.J. (1992) Trends Cell Biol. 2, 332-337

8. Berridge, M.J., and Irvine, R.F. (1989) Nature 341, 197-205

9. Payrastre, B., Nievers, M., Boonstra, J., Breton, M., Verkleij, A.J., and van Bergen en Henegouwen, P.M.P. (1992) J. Biol. Chem. 267, 50785084

10. Cross, G.A.M. (1990) Annu. Rev. Cell Biol. 6, 1-39

11. Thompson, T.E., and Tillack, T.W. (1985) Ann. Rev. Biophys. Biophys. Chem. 14, 361-386

12. Simons, K., and van Meer, G. (1988) Biochemistry 27, 6197-6202

13. van Meer, G. (1989) Annu. Rev. Cell Biol. 5, 247-275

14. Coste, H., Martel, M.B., and Got, R. (1986) Biochim. Biophys. Acta 858, 6-12

15. Futerman, A.H., and Pagano, R.E. (1991) Biochem. J. 280, 295-302

16. Jeckel, D., Karrenbauer, A., Burger, K.N.J., van Meer, G., and Wieland, F. (1992) J. Cell Biol. 117, 259-267

17. Trinchera, M., Fabbri, M., and Ghidoni, R. (1991) J. Biol. Chem. 266, 20907-20912

18. Chigorno, V., Valsecchi, M., Acquotti, D., Sonnino, S., and Tettamanti, G. (1990) FEBS Lett. 263, 329-331

19. Chan, K.-F.J., and Liu, Y. (1991) Glycobiology 1, 193-203

20. Higashi, H., Omori, A., and Yamagata, T. (1992) J. Biol. Chem. 267, 9831-9838

21. Sakakibara, K., Momoi, T., Uchida, T., and Nagai, Y. (1981) Nature 293, 76-79

22. Gillard, B.K., Thurmon, L.T., and Marcus, D.M. (1992) Cell Motil. Cytoskel. 21, 255-271

23. Wirtz, K.W.A. (1991) Annu. Rev. Biochem. 60, 73-99

24. Gascard, P., Tran, D., Sauvage, M., Sulpice, J.-C., Fukami, K., Takenawa, T., Claret, M., and Giraud, F. (1991) Biochim. Biophys. Acta 1069, 27-36

25. Helms, J.B., de Vries, K.J., and Wirtz, K.W.A. (1991) J. Biol. Chem. 266, 21368-21374

26. Smith, C.D., and Wells, W.W. (1983) J. Biol. Chem. 258, 9368-9373

27. Cocco, L., Gilmour, R.S., Ognibene, A., Letcher, A.J., Manzoli, F.A., and Irvine, R.F. (1987) Biochem. J. 248, 765-770

28. Martelli, A.M., Gilmour, R.S., Bertagnolo, V., Neri, L.M., Manzoli, L., and Cocco, L. (1992) Nature 358, $242-245$

29. Sonnenberg, A., van Balen, P., Hengeveld, T., Kolvenbag, G.J.C.M., van Hoeven, and R.P., Hilgers, J. (1986) J. Immunol. 137, 1264-1269

30. Hansson, G.C., Simons, K., and van Meer, G. (1986) EMBO J. 5, 483-489

31. Symington, F.W., Murray, W.A., Bearman, S.I., and Hakomori, S.-i. (1987) J. Biol. Chem. 262, 11356-11363

32. Butor, C., Stelzer, E.H.K., Sonnenberg, A., and Davoust, J. (1991) Eur. J. Cell Biol. 56, 269-285

33. Pagano, R.E. (1990) Curr. Opin. Cell Biol. 2, 652-663

34. Polak, J.M., and Varndell, I.M. (eds) (1984) Immunolabelling for Electron Microscopy, Elsevier Science Publishers, Amsterdam

35. Verkleij, A.J., and Leunissen, J.L.M. (eds) (1989) Immuno-gold Labeling in Cell Biology, CRC Press Inc., New York

36. Hayat, M.A. (ed) (1989-1991) Colloidal Gold. Principles, methods and application, Vol. 1-3, Academic Press Inc., New York

37. Knoll, G., Burger, K., Bron, R., van Meer, G., and Verkleij, A.J. (1988) J. Cell Biol. 107, 2511-2521

38. Boddingius, J., and Dijkman, H.P. (1989) J. Histochem. Cytochem. 37, 455-462

39. Kanai, Y., Kawakami, H., Takata, K., Kurohmaru, M., Hayashi, Y., Nishida, T., and Hirano, H. (1990) Histochemistry 94, 561-568

40. Ohtani, H., Fukushi, Y., Orikasa, S., and Nagura, H. (1991) J. Histochem. Cytochem. 39, 479-484 
41. van Genderen, I.L., van Meer, G., Slot, J.W., Geuze, H.J., and Voorhout, W.F. (1991) J. Cell Biol. 115, 1009-1019

42. Voorhout, W., van Genderen, I., van Meer, G., and Geuze, H. (1991) in Scanning Microscopy Suppl. 5, pp s17-s25, Scanning Microscopy International, Chicago

43. Stern, P.L., and Bretscher, M.S. (1979) J. Cell Biol. 82, 829-833

44. Nichols, G.E., Shiraishi, T., Allietta, M., Tillack, T.W., and Young, W.W. (1987) Biochim. Biophys. Acta 930, 154-166

45. Seybold, V., Rösner, H., Greis, C., Beck, E., and Rahmann, H. (1989) J. Neurochem. 52, 1958-1961

46. Tillack, T.W., Allietta, M., Moran, R.E., and Young, W.W. (1983) Biochim. Biophys. Acta 773, 15-24

47. Rock, P., Allietta, M., Young, W.W., Thompson, T.E., and Tillack, T.W. (1990) Biochemistry 29, 8484-8490

48. Barbosa, M.L.F., and Pinto da Silva, P. (1983) Cell 33, 959-966

49. Voorhout, W.F., Leunissen-Bijvelt, J.J.M., Leunissen, J.L.M., and Verkleij, A.J. (1985) J. Microsc. 141, 303-310

50. van Meer, G., Gumbiner, B., and Simons, K. (1986) Nature 322, 639-641

51. Kobayashi, T., Pimplikar, S.W., Parton, R.G., Bhakdi, S., and Simons, K. (1992) FEBS Lett. 300, $227-231$

52. Jeckel, D., Karrenbauer, A., Burger, K.N.J., van Meer, G., and Wieland, F. (1992) J. Cell Biol. 117, 259-267

53. Weibull, C., Villiger, W. and Carlemalm, E. (1984) J. Microsc. 134, 213-216

54. Weibull, C., and Christiansson, A. (1986) J. Microsc. 142, 79-86

55. Humbel, B., and Müller, M. (1984) in Electron Microscopy, Proc. 8th Europ. Congr. on Electron Microscopy, Vol. 3 (Csanady, A., Rohlich, P., and Szabo, D. (eds)) pp 1789-1798, Budapest

56. Verkleij, A.J., Humbel, B., Studer, D., and Müller, M. (1985) Biochim. Biophys. Acta 812, 591-594

57. Nichols, G.E., Borgman, C.A., and Young Jr., W.W. (1986) Biochem. Biophys. Res. Commun. 138, 1163-1169

58. Fukami, K., Matsuoka, K., Nakanishi, O., Yamakawa, A., Kawai, S., and Takenawa, T. (1988) Proc. Natl. Acad. Sci. USA 85, $9057-9061$

59. Miyazawa, A., Umeda, M., Horikoshi, T., Yanagisawa, K., Yoshioka, T., and Inoue, K. (1988) Mol. Immunol. 25, 1025-1031

60. Ito, E., Miyazawa, A., Takagi, H., Yoshioka, T., Horikoshi, T., Yanagisawa, K., Nakamura, T., Kudo, Y., Umeda, M., Inoue, K., and Mikoshiba, K. (1991) Neurosci. Res. 11, 179-188

Received on July 27, 1992, accepted on August 13, 1992.

\section{TIGG is the Best Journal for Advertising Glyco-products and Glyco-books!!!}

\section{ADVERTISING INFORMATION}

Style of TIGG: Letter Size

Number of Printed Issues: 1,500

Method of Printing: Offset Lithographic

Manuscript: Black and White, Camera Ready Artwork

Date of Issue: 2nd of Odd-numbered Month

Copy Deadline: 25th of Odd-numbered Month

Mechanical Data:

Rates:

Type Area $254 \mathrm{~mm} \times 178 \mathrm{~mm}$

1/2 Page $124 \mathrm{~mm} \times 178 \mathrm{~mm}, 254 \mathrm{~mm} \times 88 \mathrm{~mm}$

$\begin{array}{lr}\text { Outside Back Cover } & ¥ 150,000 \\ \text { Inside Front Cover } & ¥ 80,000 \\ \text { Inside Back Cover } & ¥ 70,000 \\ \text { Facing Matter(One Page) } & ¥ 50,000 \\ \text { Facing Matter(1/2 Page) } & ¥ 30,000\end{array}$

Contact Advertising Department, FCCA.

3-10-1 Koufudai, Fujishiro-cho, Kitasouma-gun, Ibaraki-ken 300-15, Japan (Phone: 81-297-83-7635, Telefax: 81-297-83-7645) 